\title{
Development of a PCR assay for the identification of Salmonella enterica serovar Brandenburg
}

\author{
Correspondence \\ Kalyani Perera \\ kalyani.perera@agresearch.co.nz
}

Received 7 April 2008

Accepted 30 June 2008

\author{
Kalyani Pererat and Alan Murray \\ Institute of Veterinary, Animal and Biomedical Sciences, Massey University, Palmerston North, \\ Private Bag 11 222, New Zealand
}

\begin{abstract}
Currently, Salmonella enterica serovar Brandenburg is identified serologically on the basis of two surface antigens, somatic $(\mathrm{O})$ polysaccharide and flagellar $(\mathrm{H})$ proteins. This procedure is time-consuming and requires expensive typing reagents. To overcome these problems, a PCR method was developed and validated for the identification of $S$. Brandenburg. Portions of the $\operatorname{inv} A, r f b J(B), f l i C$ and $f l j B$ genes were targeted for amplification using four pairs of oligonucleotide primers. To validate the assay, genomic DNA from an array of 72 Salmonella strains representing 28 serotypes and 5 non-Salmonella strains from 4 different genera was subjected to PCR.

The four targeted genes were correctly amplified only from $S$. Brandenburg. These results indicate that this PCR assay is a simple, rapid, reliable and reproducible method for the identification of $S$. Brandenburg that will aid in surveillance, prevention and control of this pathogen.
\end{abstract}

\section{INTRODUCTION}

Since 1996, Salmonella enterica serovar Brandenburg has been a major cause of ovine abortions and mortality, leading to significant economic impact to farmers in New Zealand (Clark, 2000; Clark et al., 2004; Roe, 1999; Smart, 2000). Sheep that have recovered from clinical disease may become carriers and excrete organisms in faeces. $S$. Brandenburg has also been isolated from humans and other animals, including horses, cattle, goats, deer, pigs and dogs. In New Zealand, human cases occurred through contact with infected animals and not through consumption of animal products (Clark et al., 2004). Therefore, rapid detection of $S$. Brandenburg would aid in controlling the spread of this pathogen to both animals and humans.

The number of Salmonella serotypes reported by 2002 was 2541 (CDC, 2007). The somatic O-antigen, together with phase-1 $(\mathrm{H} 1)$ and phase-2 (H2) flagellar antigens, forms the basis for Salmonella serotyping. Each Salmonella serotype has a unique combination of $\mathrm{O}, \mathrm{H} 1$ and $\mathrm{H} 2$ antigens. Laboratory methods for the identification of $S$. Brandenburg include serotyping, which is performed by the identification of $\mathrm{O}, \mathrm{H} 1$ and $\mathrm{H} 2$ antigens according to the Kauffmann-White scheme (Popoff \& Le Minor, 2001). This procedure is time-consuming, laborious and costly. Rapid and inexpensive PCR assays for the detection of Salmonella at the genus level have been developed (Rahn et al., 1992), but the number of assays to determine the Salmonella serotype is limited and includes those to detect serotypes Enteriditis (Lampel et al., 1996), Gallinarum (Shah et al., 2005), Typhi (Farrell et al., 2005; Kumar et al.,

tPresent address: AgResearch, National Centre for Biosecurity and Infectious Disease-Wallaceville, Upper Hutt, New Zealand.
2006) and Typhimurium (Leon-Velarde et al., 2004). To date, there is no serotype-specific PCR assay for the detection of $S$. Brandenburg.

Somatic O-antigens are polymers of the $\mathrm{O}$-subunit, and the $r f b$ gene clusters are responsible for much of its variation. Variability of $\mathrm{O}$-antigens among serogroups is due to differences in the type and arrangement of sugars in the Osubunit (Fitzgerald et al., 2003; Gillespie et al., 2003). The filament of flagella is a polymer of flagellin monomers that are composed of conserved terminal regions and a central variable region (Joys, 1985; Wei \& Joys, 1985). The latter is responsible for flagellar antigenic specificity among serotypes (Newton et al., 1991). S. Brandenburg carries serogroup B-specific $\mathrm{O}: 4$ antigen, $\mathrm{H} 1$ antigens $\mathrm{l}$, v, and $\mathrm{H} 2$ antigens e, $\mathrm{n}, \mathrm{z} 15$. These are encoded by $r f b J(\mathrm{~B})$, the $\mathrm{l}$ and $\mathrm{v}$ alleles of $f l i C$ and the e, n and z15 alleles of $f l j B$ genes, respectively. Presence of invA is specific to Salmonella, and the combination of $r f b J(\mathrm{~B}), f l i C(\mathrm{l}, \mathrm{v})$ and $f l j B(\mathrm{e}, \mathrm{n}, \mathrm{z} 15)$ is specific to $S$. Brandenburg. Therefore, the amplification of invA will differentiate Salmonella from non-Salmonella isolates, and amplification of $r f b J(B), f l i C(\mathrm{l}, \mathrm{v})$ and $f l j B$ (e, n, z15) will differentiate $S$. Brandenburg from other Salmonella serotypes. We describe here the development of a PCR method targeting invA, $r f b J(B), f l i C$ and $f l j B$ genes for the detection of $S$. Brandenburg from suspected Salmonella colonies.

\section{METHODS}

Bacterial strains. A total of 72 Salmonella strains belonging to 28 different serotypes (Table 1) and 5 non-Salmonella strains belonging to 4 different genera (Table 2) were used in this study. Salmonella serotypes carrying different $\mathrm{O}$ - and $\mathrm{H}$-antigens were used. Salmonella 
Table 1. Properties and PCR results of Salmonella strains used in this study

\begin{tabular}{|c|c|c|c|c|c|c|c|}
\hline \multirow[t]{2}{*}{ Salmonella serotype } & \multirow[t]{2}{*}{ Serogroup } & \multirow[t]{2}{*}{$\begin{array}{c}\text { Antigenic formula } \\
\mathrm{O}: \mathrm{H} 1: \mathrm{H} 2 \text { antigenic factors }\end{array}$} & \multirow[t]{2}{*}{ Number tested } & \multicolumn{4}{|c|}{$\begin{array}{l}\text { Number of strains positive } \\
\text { for target gene }\end{array}$} \\
\hline & & & & $i n v A$ & $r f b J(B)$ & fliC & $f l j B$ \\
\hline Brandenburg & $\mathrm{B}$ & $4,12: 1, \mathrm{v}: \mathrm{e}, \mathrm{n}, \mathrm{z} 15$ & 25 & 25 & 25 & 25 & 25 \\
\hline Typhimurium & $\mathrm{B}$ & $4,[5], 12: \mathrm{i}: 1,2$ & 4 & 4 & 4 & 0 & 0 \\
\hline Derby & $\mathrm{B}$ & $4,[5], 12: \mathrm{f}, \mathrm{g}:[1,2]$ & 4 & 4 & 4 & 0 & 0 \\
\hline Agona & $\mathrm{B}$ & {$[1], 4,12: \mathrm{f}, \mathrm{g}, \mathrm{s}:-$} & 4 & 4 & 4 & 0 & 0 \\
\hline Saintpaul & $\mathrm{B}$ & $1,4,[5], 12: \mathrm{e}, \mathrm{h}: 1,2$ & 1 & 1 & 1 & 0 & 0 \\
\hline Liverpool & $\mathrm{E} 4$ & $1,3,19: \mathrm{d}: \mathrm{e}, \mathrm{n}, \mathrm{z} 15$ & 1 & 1 & 0 & 0 & 1 \\
\hline Potsdam & $\mathrm{C} 1$ & $6,7: 1, \mathrm{v}: \mathrm{e}, \mathrm{n}, \mathrm{z} 15$ & 1 & 1 & 0 & 1 & 1 \\
\hline Livingstone & $\mathrm{C} 1$ & $6,7: \mathrm{d}: 1, \mathrm{w}$ & 1 & 1 & 0 & 0 & 0 \\
\hline Infantis & $\mathrm{C} 1$ & $6,7: r: 1,5$ & 1 & 1 & 0 & 0 & 0 \\
\hline Singapore & $\mathrm{C} 1$ & $6,7: \mathrm{k}: \mathrm{e}, \mathrm{n}, \mathrm{x}$ & 1 & 1 & 0 & 0 & 0 \\
\hline Newport & $\mathrm{C} 2$ & $6,8: \mathrm{e}, \mathrm{h}: 1,2$ & 4 & 4 & 0 & 0 & 0 \\
\hline Hindmarsh & $\mathrm{C} 3$ & $8: \mathrm{r}: 1,5$ & 4 & 4 & 0 & 0 & 0 \\
\hline Gallinarum & D1 & $9,12:-:-$ & 1 & 1 & 0 & 0 & 0 \\
\hline Enteritidis & D1 & $9,12: \mathrm{g}, \mathrm{m}:[1,7]$ & 3 & 3 & 0 & 0 & 0 \\
\hline Azteca & $\mathrm{B}$ & $4,5,12: 1, \mathrm{v}: 1,5$ & 1 & 1 & 1 & 1 & 0 \\
\hline Bredeney & $\mathrm{B}$ & $1,4,12,27: 1, \mathrm{v}: 1,7$ & 1 & 1 & 1 & 1 & 0 \\
\hline Jos & $\mathrm{B}$ & $1,4,12,27: y: e, n, z 15$ & 1 & 1 & 1 & 0 & 1 \\
\hline Budapest & $\mathrm{B}$ & $1,4,12,27: \mathrm{g}, \mathrm{t}:-$ & 1 & 1 & 1 & 0 & 0 \\
\hline Abortusovis & $\mathrm{B}$ & $4,12: c: 1,6$ & 1 & 1 & 1 & 0 & 0 \\
\hline Wien & $\mathrm{B}$ & $1,4,12,27: b: 1, w$ & 1 & 1 & 1 & 0 & 0 \\
\hline Ball & $\mathrm{B}$ & $1,4,12,27: y: e, n, x$ & 1 & 1 & 1 & 0 & 0 \\
\hline Gloucester & $\mathrm{B}$ & $1,4,12,[27]: \mathrm{i}: 1, \mathrm{w}$ & 1 & 1 & 1 & 0 & 0 \\
\hline Mono & $\mathrm{B}$ & $4,12: 1, \mathrm{w}: 1,5$ & 1 & 1 & 1 & 0 & 0 \\
\hline Togo & $\mathrm{B}$ & $4,12: 1, \mathrm{w}: 1,6$ & 1 & 1 & 1 & 0 & 0 \\
\hline Havana & G2 & {$[1], 13,23: \mathrm{f}, \mathrm{g},[\mathrm{s}]:-$} & 1 & 1 & 0 & 0 & 0 \\
\hline Cerro & $\mathrm{K}$ & $18: \mathrm{z} 4, \mathrm{z} 23:[1,5]$ & 4 & 4 & 0 & 0 & 0 \\
\hline Anatum & E1 & $3,10: e, h: 1,6$ & 1 & 1 & 0 & 0 & 0 \\
\hline Newington & E2 & $3,15: e, h: 1,6$ & 1 & 1 & 0 & 0 & 0 \\
\hline
\end{tabular}

serotypes Potsdam and Livingstone were obtained from the New Zealand Reference Culture Collection, Medical Section, Institute of Environmental Science \& Research, Porirua, Wellington, New Zealand. Professor Peter R. Reeves (Department of Microbiology, University of Sydney, Australia) kindly provided genomic DNA of Salmonella strains Abortusovis, Azteca, Ball, Bredeney, Budapest, Jos, Gloucester, Mono, Togo and Wien. All other Salmonella and nonSalmonella strains were obtained from the Institutes of Veterinary,

Table 2. PCR results of non-Salmonella strains used in this study

\begin{tabular}{|lccccc|}
\hline $\begin{array}{l}\text { Non-Salmonella } \\
\text { strain }\end{array}$ & $\begin{array}{c}\text { Number } \\
\text { tested }\end{array}$ & $\begin{array}{c}\text { Number of strains positive } \\
\text { for target gene }\end{array}$ \\
\cline { 2 - 6 } & & $\mathbf{i n v A}$ & $\boldsymbol{r f b J ( B )}$ & fliC & fljB \\
\hline Escherichia coli & 1 & 0 & 0 & 0 & 0 \\
Klebsiella aerogenes & 1 & 0 & 0 & 0 & 0 \\
Klebsiella edwardsii & 1 & 0 & 0 & 0 & 0 \\
Proteus mirabilis & 1 & 0 & 0 & 0 & 0 \\
Shigella flexneri & 1 & 0 & 0 & 0 & 0 \\
\hline
\end{tabular}

Animal \& Biomedical Sciences (IVABS) and Molecular Biosciences (IMBS) of Massey University, Palmerston North, New Zealand.

DNA extraction. Genomic DNA was extracted from cell suspensions of bacteria grown overnight on xylose-lysine-deoxycholate (XLD) agar at $37{ }^{\circ} \mathrm{C}$. A single colony was resuspended in $30 \mu \mathrm{l}$ distilled water and boiled at $100{ }^{\circ} \mathrm{C}$ for $10 \mathrm{~min}$. The sample was immediately cooled on ice for $5 \mathrm{~min}$, and centrifuged at $13000 \mathrm{~g}$ at $4{ }^{\circ} \mathrm{C}$ for $10 \mathrm{~min}$. The supernatant, containing DNA, was used as the template for PCR amplification.

PCR primers. The target genes selected in this study were invA (Salmonella-specific), $r f b J(\mathrm{~B})$ (serogroup B), $f l i C(\mathrm{l}, \mathrm{v})$ and $f l j B(\mathrm{e}, \mathrm{n}$, z15). Oligonucleotide primers (Table 3 ) used for the amplification of invA, $r f b J(B)$ and $f l j B$ genes were from Rahn et al. (1992), Luk et al. (1993) and Echeita et al. (2002), respectively; the pair used for amplification of $f l i C$ was designed using the sequence of region IV of the variable domain of $S$. Brandenburg fliC gene (GenBank accession number AY935580). All primers were synthesized by Life Technologies in the desalted form.

DNA amplification and detection. The invA, fliC and $f l j B$ genes were amplified in a multiplex PCR and the $r f b J(B)$ gene was amplified in a separate reaction. Multiplex PCR amplification was performed in $0.2 \mathrm{ml}$ thin-walled PCR tubes in a reaction volume of $50 \mu \mathrm{l}$, consisting $1 \mu \mathrm{l}$ genomic DNA, $200 \mathrm{nM}$ each primer invAF, invAR, 
Table 3. PCR primers ( $F$, forward and $R$, reverse) used in this study

\begin{tabular}{|c|c|c|c|c|}
\hline Target gene & Primer & Primer sequence $\left(5^{\prime}-3^{\prime}\right)$ & Position & Size $(b p)$ \\
\hline \multirow[t]{2}{*}{$i n v A$} & $i n v A \mathrm{~F}$ & GTGAAATTATCGCCACGTTCGGGCAA & $371-396$ & 285 \\
\hline & invAR & TCATCGCACCGTCAAAGGAACC & $655-634$ & \\
\hline$r f b J(B)$ & $r f b J(\mathrm{~B}) \mathrm{R}$ & TAACCGTTTCAGTAGTTC & $897-880$ & \\
\hline \multirow[t]{2}{*}{ fliC } & fliCF & CACTGGTCTTAATGATGCAGCTC & $588-610$ & 222 \\
\hline & fliCR & CCTGTCACTTTCGTGGTTAT & $809-790$ & \\
\hline$f l j B$ & $f l j B R$ & ATCAACGGTAACTTCATATTTG & $765-744$ & \\
\hline
\end{tabular}

fliCF, fliCR, fljBF and $f l j B R, 200 \mu \mathrm{M}$ each of dCTP, dGTP, dATP and dTTP, $2 \mathrm{mM} \mathrm{MgCl}_{2}, 1 \times$ PCR buffer [20 mM Tris/HCl (pH 8.4), $50 \mathrm{mM} \mathrm{KCl}$, $1.25 \mathrm{U}$ of Platinum Taq DNA Polymerase (Life Technologies) and sterile distilled water. The reactions were subjected to a single cycle of denaturation at $95{ }^{\circ} \mathrm{C}$ for $5 \mathrm{~min}$, followed by 30 cycles of denaturation $\left(95{ }^{\circ} \mathrm{C}\right.$ for $\left.1 \mathrm{~min}\right)$, annealing $\left(60{ }^{\circ} \mathrm{C}\right.$ for $\left.30 \mathrm{~s}\right)$, elongation $\left(72{ }^{\circ} \mathrm{C}\right.$ for $\left.30 \mathrm{~s}\right)$ and a final elongation $\left(72{ }^{\circ} \mathrm{C}\right.$ for $\left.7 \mathrm{~min}\right)$ in a GeneAmp 9600 thermocycler (Perkin Elmer). The $r f b J(B)$ gene was amplified separately in a $50 \mu \mathrm{l}$ reaction volume containing the same PCR reagents as the multiplex reaction, replacing the primers with $r f b J(\mathrm{~B}) \mathrm{F}$ and $r f b J(\mathrm{~B}) \mathrm{R}$. The thermocycler parameters were as above, except that annealing was done at $55{ }^{\circ} \mathrm{C}$ for $1 \mathrm{~min}$ and elongation was at $72{ }^{\circ} \mathrm{C}$ for $1 \mathrm{~min}$. A negative control containing sterile distilled water in place of genomic DNA was included in each PCR assay. Reproducibility of the assay was confirmed by testing each strain in duplicate three times. The completed reactions were held at $4{ }^{\circ} \mathrm{C}$ for direct use or stored at $-20{ }^{\circ} \mathrm{C}$.

Multiplex PCR-amplified sample $(10 \mu \mathrm{l})$ was mixed with $10 \mu \mathrm{l}$ of the single reaction and electrophoresed on $2.5 \%(\mathrm{w} / \mathrm{v})$ agarose gels in $1 \times$ TAE buffer. One-kb plus DNA ladder marker (Life Technologies) was used as a size reference. Following electrophoresis, gels were stained with $0.5 \mu \mathrm{g}$ ethidium bromide $\mathrm{ml}^{-1}$ and visualized on a UV transilluminator. The four PCR products obtained from $S$. Brandenburg amplification were excised from the agarose gel and purified using the QIAquick gel extraction kit (Qiagen). Products were sequenced by the Sequencing Facility of Massey University with the ABI Prism BigDye Terminator Sequencing Reaction kit on a Capillary ABI3730 DNA analyser (Applied Biosystems). DNA sequences were edited using Chromas software and analysed with the BLASTN network server at http://www.ncbi.nlm.nih.gov/blast/.

Validation. Genomic DNA extracted from a panel of Salmonella strains representing 28 different serotypes and non-Salmonella strains from 4 genera were PCR-amplified to evaluate the validity of the PCR assay.

\section{RESULTS AND DISCUSSION}

Preliminary experiments to amplify invA, fliC, $f l j B$ and $r f b J(B)$ in a multiplex PCR did not yield consistent results with the $r f b J(\mathrm{~B})$ gene. Therefore, this segment was amplified in a separate reaction. Fig. 1 shows the amplification products from a representative number of Salmonella strains used in the study. The invA gene was amplified in all Salmonella isolates but the $r f b J(\mathrm{~B})$ gene was only amplified in serogroup B isolates. While fliC primers amplified only the Salmonella isolates carrying l, v alleles, $f l j B$ primers amplified only those carrying e, n, z15 alleles (Table 1). The non-Salmonella strains did not produce amplification products under these conditions (Table 2). Only $S$. Brandenburg strains gave all four amplification

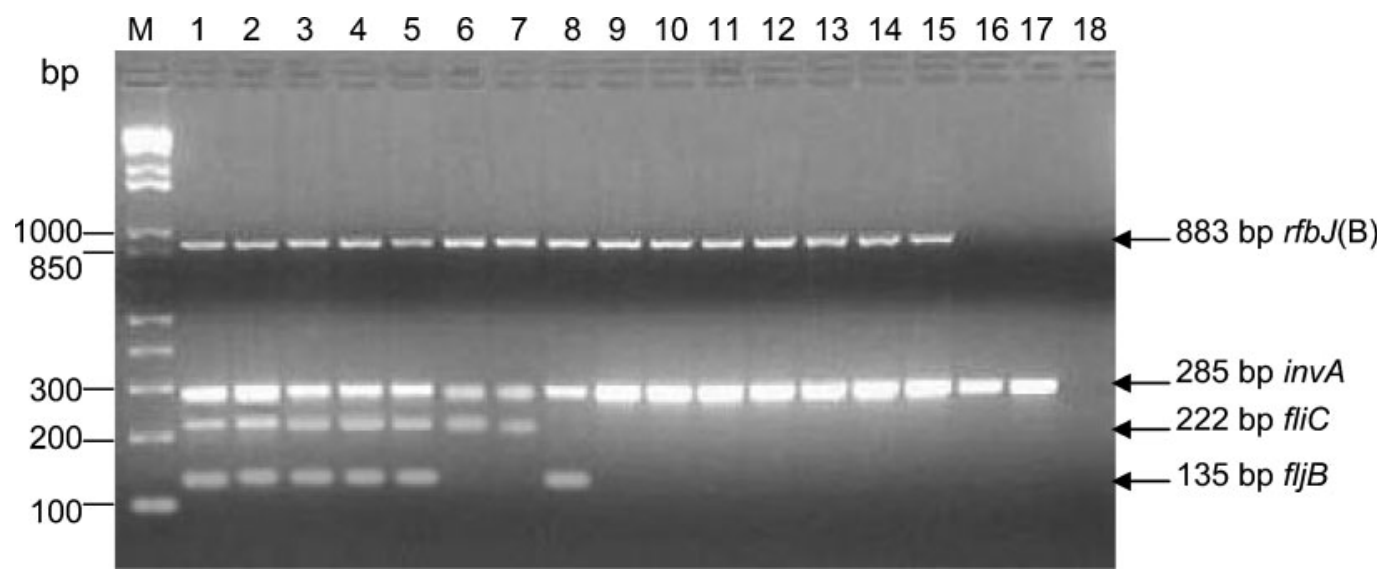

Fig. 1. PCR amplification of $i n v A, r f b J(B), f l i C(l, v)$ and $f l j B(e, n, z 15)$ genes. PCR products were electrophoresed on a $2.5 \%$ $(\mathrm{w} / \mathrm{v})$ agarose gel, stained with ethidium bromide and photographed under UV light. Lanes: M, One-kb plus DNA ladder marker; 1-5, S. Brandenburg; 6, S. Azteca; 7, S. Bredeney; 8, S. Jos; 9, S. Budapest; 10, S. Abortusovis; 11, S. Wien; 12, S. Ball; 13, S. Gloucester; 14, S. Mono; 15, S. Togo; 16, S. Havana; 17, S. Newington; 18, Klebsiella edwardsii. 
products of the expected sizes of $883 \mathrm{bp}(\mathrm{rfbJ \textrm {B }}), 285 \mathrm{bp}$ (invA), $222 \mathrm{bp}(f l i C)$ and $135 \mathrm{bp}(f l j B)$. The primer pair sets did not show any cross-reactivity with Salmonella strains harbouring other somatic and flagellin gene groups. Sequencing and BLASTN analysis of the amplicons of $S$. Brandenburg confirmed that only the correct gene fragments had been amplified. All $25 \mathrm{~S}$. Brandenburg isolates used in this study amplified all 4 genes. Repeated PCRs gave identical results.

The PCR assay developed in this study was based on the amplification of $i n v A, r f b J(B), f l i C$ and $f l j B$ genes directly from a single Salmonella colony. invA was targeted for the diagnosis of Salmonella organisms at the genus level, and the combination of three polymorphic genes, $r f b J(B), f l i C$ and $f l j B$, was targeted for the identification of $S$. Brandenburg at the serotype level. invA, located on the pathogenicity island 1 of Salmonella species, is essential for invasion of epithelial cells (Collazo \& Galán, 1997). It is present in all invasive strains of Salmonella (Galán, 1996) and absent from closely related genera such as Escherichia (Bäumler et al., 1998). The invA gene was amplified from all 72 Salmonella strains, while it was not amplified from non-Salmonella strains belonging to the 4 genera. These results agree with Rahn et al. (1992), who designed and established the specificity of this widely used pair of primers. They showed that 630 Salmonella strains representing over 100 serotypes yielded the target band of $285 \mathrm{bp}$, whereas two strains from each of the serotypes Litchfield and Senftenberg were negative. The strains that were shown to lack invA sequences were from environmental samples and were not specifically associated with disease (Ginocchio et al., 1997). Furthermore, the invA primer pair was also used in a European research project in the validation and standardization of PCR for the detection of Salmonella species in food (Hoorfar, 1999). Malorny et al. (2003) showed that one S. Saintpaul strain did not give the target band. It is speculated that invA is absent in these strains, which are not invasive, or that they might be using other invasive mechanisms. However, absence of invA in Salmonella seems to be rare (Malorny et al., 2003).

The lipopolysaccharide $\mathrm{O}$-antigen together with $\mathrm{H} 1$ and $\mathrm{H} 2$ flagellar antigens forms the basis for Salmonella serotyping (Popoff \& Le Minor, 2001). The O-antigen specificity is based on the sugar composition and arrangement in the O-subunit (Fitzgerald et al., 2003). The O-subunit of serogroup B salmonellae is an oligosaccharide of four sugar residues. Of these four sugars, three form a mannosylrhamnosyl-galactose backbone common to some other serogroups such as A and D. The fourth sugar is a dideoxyhexose substituted on the mannosyl residue. While the dideoxyhexose sugar present in the O-subunit of serogroups $\mathrm{A}$ and $\mathrm{D}$ is paratose and tyvelose, respectively, that of both serogroups B and C2 is abequose. Abequose confers on serogroup B strains their specific $\mathrm{O}: 4$ antigen (Wyk \& Reeves, 1989). The $r f b$ gene cluster encodes the enzymes for biosynthesis of $\mathrm{O}$-antigens. The $r f b J$ gene encodes abequose synthase, which is responsible for the final specific step in the synthesis of abequose. There is a $44 \%$ difference between the nucleotide sequence of $r f b J$ gene of serogroup B $[r f b J(B)]$ and that of serogroup C2 $[r f b J(C 2)]$ (Luk et al., 1993; Wyk \& Reeves, 1989). Luk et al. (1993) designed a pair of primers targeting the serogroup B specific $r f b J$ gene that was used in this study and as expected, it amplified only the $r f b J(B)$ gene. In $S$. Brandenburg, $\mathrm{H} 1$ and $\mathrm{H} 2$ flagellins belong to the L- (l, v) and E-complex (e, n, z15), respectively. Region IV of Salmonella flagellin is the most variable, and is believed to carry the major serotype-specific epitopes of the flagellar antigens (Newton et al., 1991; Wei \& Joys, 1985). Some of the flagellar antigens are composed of a single antigenic factor $(b, c, d, i, r)$ while others are composed of multiple antigenic factors $(\mathrm{l}, \mathrm{v} ; \mathrm{l}, \mathrm{w} ; \mathrm{e}, \mathrm{h} ; \mathrm{e}, \mathrm{n}, \mathrm{x} ; \mathrm{e}, \mathrm{n}, \mathrm{z} 15 ; 1$, 2 ). Flagellar antigens are grouped into complexes depending on the antigenic factors that they share. Examples are the E-complex, which contains antigenic factor e (e, h; e, n, x; e, $\mathrm{n}, \mathrm{z15}$ ) and the L-complex, which contains antigenic factor 1 (l, v; l, w; l, z13, l, z28) (Popoff \& Le Minor, 2001). The two primer pairs used to amplify $f l i C$ and $f l j B$ (Echeita et al., 2002) were from region IV of the variable region and did not amplify other E- and L-complex genes of the Salmonella strains used in this study. This shows the specificity of these two pairs of primers for $\mathrm{l}, \mathrm{v}$ and $\mathrm{e}, \mathrm{n}, \mathrm{z} 15$ alleles of $f l i C$ and $f l j B$ genes, respectively.

All of the $S$. Brandenburg strains in this study were obtained from clinical samples (uterine swabs, faeces, intestinal contents and meat) collected from sheep, cattle and pigs, and sheep yard dust. Pure cultures of $S$. Brandenburg were used for the initial evaluation of the assay because PCR assays are prone to inhibition by substances in the samples (Iijima et al., 2004). All 25 S. Brandenburg cultures that were confirmed by serotyping were positive in the PCR, with no false-negative reactions. The PCR described here detected the combination of three genes $[r f b J(B), f l i C(\mathrm{l}, \mathrm{v})$ and $f l j B$ $(\mathrm{e}, \mathrm{n}, \mathrm{z} 15)]$ that is unique to $S$. Brandenburg. A combination of enrichment, subcultures, biochemical tests and serotyping is currently used for the identification of $S$. Brandenburg and the whole process normally takes approximately 7 days. With the PCR assay described in this study, identification of pure cultures of Salmonella to the serotype Brandenburg could be done in approximately $8 \mathrm{~h}$. In total, the time taken from receipt of the clinical sample to confirming the identity of the organism by this PCR assay will be approximately 4 days. Since this assay requires only genomic DNA, it does not depend on the expression of antigens, thus making the need for time-consuming phase reversal of flagellin antigens unnecessary.

The PCR assay described here will be a useful complement to traditional culture and serotyping techniques for the identification of $S$. Brandenburg in clinical samples.

\section{ACKNOWLEDGEMENTS}

The authors wish to thank IVABS at Massey University for providing financial support of this project through the Postgraduate Research Fund and a Lewis Fitch Grant. We also wish to thank Associate 
Professor Stanley Fenwick at Murdoch University, Australia, for his input, Professor Peter R. Reeves and Gordon Stevenson at University of Sydney for providing us with genomic DNA from some of the Salmonella isolates, and Barbara Asmundson at Massey University for her help with some Salmonella cultures. Kalyani Perera is grateful to Massey University for the Massey Doctoral Scholarship.

\section{REFERENCES}

Bäumler, A. J., Tsolis, R. M., Ficht, T. A. \& Adams, L. G. (1998). Evolution of host adaptation in Salmonella enterica. Infect Immun 66, 4579-4587.

CDC (2007). Salmonella Surveillance: Annual Summary, 2005. Atlanta, GA: US Department of Health and Human Services, Centers for Disease Control and Prevention.

Clark, G. (2000). Salmonella Brandenburg-update 2000. In Vetscript (December), pp. 16-17. Wellington: New Zealand Veterinary Association.

Clark, R. G., Fenwick, S. G., Nicol, C. M., Marchant, R. M., Swanney, S., Gill, J. M., Holmes, J. D., Leyland, M. \& Davies, P. R. (2004). Salmonella Brandenburg - emergence of a new strain affecting stock and humans in the South Island of New Zealand. N Z Vet J 52, 26-36.

Collazo, C. M. \& Galán, J. E. (1997). The invasion-associated type-III protein secretion system in Salmonella - a review. Gene 192, 51-59.

Echeita, M. A., Herrera, S., Garaizar, J. \& Usera, M. A. (2002). Multiplex PCR-based detection and identification of the most common Salmonella second-phase flagellar antigens. Res Microbiol 153, 107-113.

Farrell, J. J., Doyle, L. J., Addison, R. M., Reller, L. B., Hall, G. S. \& Procop, G. W. (2005). Broad-range (pan) Salmonella and Salmonella serotype Typhi-specific real-time PCR assays: potential tools for the clinical microbiologist. Am J Clin Pathol 123, 339-345.

Fitzgerald, C., Sherwood, R., Gheesling, L. L., Brenner, F. W. \& Fields, P. I. (2003). Molecular analysis of the $r f b \mathrm{O}$ antigen gene cluster of Salmonella enterica serogroup O:6,14 and development of a serogroup-specific PCR assay. Appl Environ Microbiol 69, 6099-6105.

Galán, J. E. (1996). Molecular genetic bases of Salmonella entry into host cells. Mol Microbiol 20, 263-271.

Gillespie, B. E., Mathew, A. G., Draughon, F. A., Jayarao, B. M. \& Oliver, S. P. (2003). Detection of Salmonella enterica somatic groups $\mathrm{C} 1$ and E1 by PCR-enzyme-linked immunosorbent assay. J Food Prot 66, 2367-2370.

Ginocchio, C. C., Rahn, K., Clarke, R. C. \& Galán, J. E. (1997). Naturally occurring deletions in the centisome 63 pathogenicity island of environmental isolates of Salmonella spp. Infect Immun 65, 1267-1272.

Hoorfar, J. (1999). EU seeking to validate and standardize PCR testing of food pathogens. ASM News 65, 799.

lijima, Y., Asako, N. T., Aihara, M. \& Hayashi, K. (2004). Improvement in the detection rate of diarrhoeagenic bacteria in human stool specimens by a rapid real-time PCR assay. J Med Microbiol 53, 617-622.

Joys, T. M. (1985). The covalent structure of the phase-1flagellar filament protein of Salmonella typhimurium and its comparison with other flagellins. J Biol Chem 260, 15758-15761.

Kumar, S., Balakrishna, K. \& Batra, H. V. (2006). Detection of Salmonella enterica serovar Typhi ( $S$. Typhi) by selective amplification of invA, viaB, fliC-d and prt genes by polymerase chain reaction in mutiplex format. Lett Appl Microbiol 42, 149-154.

Lampel, K. A., Keasler, S. P. \& Hanes, D. E. (1996). Specific detection of Salmonella enterica serotype Enteritidis using the polymerase chain reaction. Epidemiol Infect 116, 137-145.

Leon-Velarde, C. G., Cai, H. Y., Larkin, C., Bell-Rogers, P., Stevens, R. W. C. \& Odumeru, J. A. (2004). Evaluation of methods for the identification of Salmonella enterica serotype Typhimurium DT104 from poultry environmental samples. J Microbiol Methods 58, 79-86.

Luk, J. M. C., Kongmuang, U., Reeves, P. R. \& Lindberg, A. A. (1993). Selective amplification of abequose and paratose synthase genes $(r f b)$ by polymerase chain reaction for identification of Salmonella major serogroups (A, B, C2, and D). J Clin Microbiol 31, 2118-2123.

Malorny, B., Hoorfar, J., Bunge, C. \& Helmuth, R. (2003). Multicenter validation of the analytical accuracy of Salmonella PCR: towards an international standard. Appl Environ Microbiol 69, 290-296.

Newton, S. M. C., Wasley, R. D., Wilson, A., Rosenberg, L. T., Miller, J. F. \& Stocker, B. A. D. (1991). Segment IV of a Salmonella flagellin gene specifies flagellar antigen epitopes. Mol Microbiol 5, 419-425.

Popoff, M. Y. \& Le Minor, L. (2001). Antigenic Formulas of the Salmonella Serovars, 8th revision. WHO Collaborating Centre for Reference and Research on Salmonella. Paris: Institut Pasteur.

Rahn, K., De Grandis, S. A., Clarke, R. C., McEwen, S. A., Galán, J. E., Ginocchio, C., Curtiss, R., III \& Gyles, C. L. (1992). Amplification of an invA gene sequence of Salmonella typhimurium by polymerase chain reaction as a specific method of detection of Salmonella. Mol Cell Probes 6, 271-279.

Roe, A. (1999). Salmonella Brandenburg: a practitioner's perspective. In Proceedings of the 29th Annual Seminar of the Society of Sheep and Beef Cattle Veterinarians of the New Zealand Veterinary Association, pp. 23-28.

Shah, D. H., Park, J.-H., Cho, M.-R., Kim, M.-C. \& Chae, J.-S. (2005). Allele-specific PCR method based on $r f b S$ sequence for distinguishing Salmonella gallinarum from Salmonella pullorum: serotype-specific $r f b S$ sequence polymorphism. J Microbiol Methods 60, 169-177.

Smart, J. A. (2000). Latest experiences of Salmonella Brandenburg. In Proceedings of the 30th Annual Seminar of the Society of Sheep and Beef Cattle Veterinarians of the New Zealand Veterinary Association, pp. 137-150.

Wei, L.-N. \& Joys, T. M. (1985). Covalent structure of three phase-1 flagellar filament proteins of Salmonella. J Mol Biol 186, 791-803.

Wyk, P. \& Reeves, P. (1989). Identification and sequence of the gene for abequose synthase, which confers antigenic specificity on group B salmonellae: homology with galactose epimerase. J Bacteriol 171, 5687-5693. 